\title{
PENGARUH PENERAPAN MODEL PEMBELAJARAN PROBLEM BASED LEARNING TERHADAP PEMAHAMAN KONSEP SISWA
}

\author{
Hanifah Rahmadani \\ Arrofa Acesta \\ PGSD Fakultas Keguruan dan Ilmu Pendidikan \\ Universitas Kuningan
}

\begin{abstract}
This study aims to determine the effect of application of the model Problem Based Learning on the understanding of the concept of V grade students of SD Negeri Unggulan Kuningan on the subjects of Social Studies IPS concept of Nature and Artificial in Indonesia. This research is a type of Quasi Experimental Design, while the research design using Nonequivalent Control Group Design. The subjects of this study are all students of VA class which amounted to 25 students and VB which amounted to 27 students in Kuningan Elementary State Elementary School. The results showed that the model of Problem Based Learning influenced the students' concept of understanding. This can be seen from the significant differences between the two sample groups, the difference is the average value of pretest $=53.11$ to 79.85 in the posttest of the experimental students' learning result. While the students' learning outcomes control group pretest average value $=49.6$ to 59.4 on posttest. And based on t test results, showed that the value of $t$-count $=$ 6.50 with $95 \%$ significance obtained $t$-tabel $=2.96$. Then thitung $(6.50)>t$-table (2.96), meaning that the model of Problem Based Learning has a significant effect on understanding the concept of students
\end{abstract}

\section{Keywords: Problem Based Learning Model, Understanding Student Concept}

\begin{abstract}
Abstrak: Penelitian ini bertujuan untuk mengetahui pengaruh penerapan model Problem Based Learning terhadap pemahaman konsep siswa kelas V SD Negeri Unggulan Kuningan pada mata pelajaran IPS konsep Kenampakan Alam dan Buatan di Indonesia. Penelitian ini merupakan jenis Quasi Experimental Design, sedangkan desain penelitiannya menggunakan Nonequivalent Control Group Design. Subjek penelitian ini adalah seluruh siswa kelas VA yang berjumlah 25 siswa dan VB yang berjumlah 27 siswa di SD Negeri Unggulan Kuningan. Hasil penelitian menunjukkan bahwa model Problem Based Learning berpengaruh terhadap pemahaman konsep siswa. Hal tersebut dapat dilihat dari adanya perbedaan yang signifikan antara kedua kelompok sampel, perbedaannya yaitu nilai rata-rata pretest $=53,11$ menjadi 79,85 pada posttest hasil belajar siswa kelas eksperimen. Sedangkan hasil belajar siswa kelompok kontrol nilai rata-rata pretest = 49,6 menjadi 59,4 pada posttest . Dan berdasarkan hasil uji t, menunjukan bahwa nilai $\mathrm{t}_{\text {-hitung }}=6,50$ dengan signifikansi $95 \%$ diperoleh $\mathrm{t}$-tabel $=2,96$. Maka $\mathrm{t}_{\text {-hitung }}$ $(6,50)>\mathrm{t}$-tabel $(2,96)$, artinya bahwa model Problem Based Learning berpengaruh signifikan terhadap pemahaman konsep siswa.
\end{abstract}

Kata kunci: Model Problem Based Learning, Pemahaman Konsep Siswa 


\section{PENDAHULUAN}

Pendidikan merupakan salah satu sektor yang memiliki peran penting dalam pembangunan nasional, serta upaya menyiapkan kualitas sumber daya manusia. Pendidikan mengusahakan suatu lingkungan yang memungkinkan perkembangan bakat, minat, dan kemampuan peserta didik secara optimal. Hal tersebut sesuai dengan tujuan dan fungsi pendidikan yang tersirat dalam Undang-Undang RI No.20 Tahun 2003 tentang Sistem Pendidikan Nasional.

Berkaitan dengan pendidikan khususnya pendidikan pada jenjang Sekolah Dasar hingga saat ini masih kurang dari harapan, hal ini karena masih banyak kritik yang di tujukan pada cara guru mengajar yang terlalu menekankan pada penguasaan sejumlah informasi atau konsep belaka. Penumpukan informasi atau konsep pada siswa menjadi kurang bermanfaat bahkan bisa menjadi tidak bermanfaat sama sekali. Jika hal tersebut hanya sekedar mentransferkan pengetahuan satu arah namun belum tentu memberikan pemahaman. Tidak dapat disangkal bahwa konsep merupakan satu hal yang sangat penting, namun bukan terletak pada konsep itu sendiri, tetapi terletak bagaimana konsep tersebut dapat dipahami oleh siswa.

Berdasarkan hasil tes awal yang dilakukan oleh peneliti di SD N Unggulan Kuningan, didapatkan data bahwa Kriteria Ketuntasan Minimal (KKM) pada mata pelajaran Ilmu Pengetahuan Sosial yaitu 70. Namun ternyata kenyataan menunjukkan bahwa tes awal nilai mata pelajaran Ilmu Pengetahuan Sosisal di kelas V SD N Unggulan Kuningan masih rendah. Hanya 24 orang dari 52 siswa yang mampu mencapai nilai KKM 70.

Rendahnya hasil belajar pada mata pelajaran IPS tersebut, dapat dipengaruhi oleh banyak faktor, salah satu yang diduga berpengaruh terhadap hasil belajar dan tingkat pemahaman siswa pada konsep mata pelajaran IPS adalah metode dan model pembelajaran yang digunakan. Kondisi pembelajaran IPS di SD Negeri Unggulan saat ini masih cenderung menggunakan metode pembelajaran konvensional seperti ceramah. Metode ceramah lebih menitik beratkan guru sebagai pusat informasi dan hanya menyalurkan ilmu kepada siswanya (teacher centre), sedangkan siswa hanya menjadi pendengar dan penerima saja. Dengan demikian, siswa seringkali merasa bosan dan cenderung bersifat tidak terkendali 
dalam menerima informasi, serta bermain-main pada saat guru menerangkan bahkan siswa menjadi pasif dan tidak antusias dalam proses pembelajaran berlangsung yang berdampak pada tidak berhasilnya siswa dalam pembelajaran IPS.

Oleh karena itu, untuk mempermudah siswa dalam memahami konsep yang diberikan oleh guru, salah satunya dengan menerapkan model pembelajaran Problem Based Learning (PBL) yang diperkenalkan oleh John Dewey 1859, dimana pentingnya model ini adalah learning by doing yaitu pembelajaran berbasis masalah. Sesuai dengan namanya dalam model ini setiap siswa dibagi ke dalam kelompok kecil terdiri dari 3 sampai 5 orang, kemudian siswa mencari permasalahan yang berhubungan dengan materi atau konsep. Kemudian mengeksplorasi permasalahan dengan merumuskan masalah, merumuskan hipotesis, mengumpulkan data dan menguji hipotesis. Siswa melaporkan apa yang telah dilakukan, melengkapi lembar kerja, dan merencanakan untuk tugas-tugas berikutnya. Masing-masing kelompok mempersentasikan hasil temuan tentang topik proyek yang mereka pelajari.

Arends (1997:157) mengemukakan bahwa Pembelajaran Berdasarkan Masalah (Problem Based Instruction) merupakan suatu pendekatan pembelajaran di mana siswa mengerjakan permasalahan yang autentik dengan maksud untuk menyusun pengetahuan mereka sendiri, mengembangkan inkuiri dan keterampilan berfikir tingkat lebih tinggi, mengembangkan kemandirian dan percaya diri.

Kemudian menurut Abidin (dalam Oktafouran dan Intansari, 2016) Model pembelajaran Problem Based Learning (pembelajaran berbasis masalah) adalah model pembelajaran yang ditujukan untuk mengembangkan motivasi belajar siswa, mendorong siswa untuk mampu berpikir tingkat tinggi, mendorong siswa mengoptimalkan kemampuan metakognisinya, dan menjadi pembelajaran mejadi bermakna sehingga mendorong siswa memiliki rasa percaya diri yang tinggi dan mampu belajar secara mandiri.

Berdasarkan pendapat para ahli di atas, maka penulis menyimpulkan bahwa Problem Based Learning atau Pembelajaran Berbasis Masalah ini dapat diartikan sebagai cara sistematis untuk melakukan suatu investigasi atau penelitian terhadap 
masalah dan menentukan solusi untuk kemudian diterapkan. Kemudian, digunakan untuk mendeskripsikan metode belajar yang mengembangkan wawasan baru dan proses berpikir melalui belajar aktif dengan cara melakukan penelitian.

Ilmu Pengetahuan Sosial (IPS) merupakan integrasi dari berbagai cabang ilmuilmu sosial dan humaniora, yaitu: sosiologi, sejarah, geografi, ekonomi, politik, hukum dan budaya. Ilmu pengetahuan sosial dirumuskan atas dasar realitas dan fenomena sosial yang mewujudkan satu pendekatan interdisipliner dari aspek dan cabang-cabang ilmu sosial diatas. (Susanto, 2014).

\section{METODE PENELITIAN}

Penelitian dilakukan pada semester ganjil tahun ajaran 2016/2017. Subjek penelitian adalah siswa-siswi di SD N Unggulan Kuningan yang berjumlah 52 orang terdiri atas 25 siswa kelas VA dan 27 siswa kelas VB. Teknik pengumpulan data pada penelitian ini melalui tes, dan dokumentasi.. Penelitian ini bertujuan untuk meningkatkan pemahaman konsep siswa pada mata pelajaran Ilmu Pengetahuan Sosial kelas V, materi Kenampakan Alam dan Buatan di Indonesia, di SD N Unggulan Kuningan melalui model pembelajaran Problem Based Learning.

Pelaksanaan penelitian eksperimen ini dilaksanakan di SD $\mathrm{N}$ Unggulan Kuningan yang berlokasi di Desa Cikaso Kecamatan Kramatmulya Kabupaten Kuningan. Analisis data yang diterapkan dalam penelitian ekperimen ini adalah dengan cara melakukan proses pembelajaran di dua kelas yaitu kelas VA dan Kelas VB. Kelas VA merupakan kelas kontrol yaitu kelas yang menggunakan metode konvensional dan kelas VB merupakan kelas eksperimen yang menggunakan model pembelajaran Problem Based Learning.

\section{HASIL DAN PEMBAHASAN}

Sebelum penelitian ini dilaksanakan, peneliti terlebih dahulu memberikan pretest tujuannya adalah untuk mengetahui kemampuan awal siswa pada kelas ekperimen dan kelas kontrol. 


\section{Deskripsi Kemampuan Awal Siswa kelas Kontrol dan Kelas Eksperimen.}

\begin{tabular}{|c|l|c|c|}
\hline \multirow{2}{*}{ NO } & \multirow{2}{*}{ Data Penelitian } & \multicolumn{2}{|c|}{ Kelompok } \\
\cline { 3 - 4 } & & Kontrol & Eksperimen \\
\hline 1 & Jumlah siswa & 25 & 27 \\
\hline 2 & Skor max & 80 & 80 \\
\hline 3 & Skor min & 27 & 33 \\
\hline 4 & Rata-rata skor & 49,6 & 53,11 \\
\hline 5 & Standar deviasi & 13,29 & 8,82 \\
\hline
\end{tabular}

Berdasarkan tabel di atas dapat diketahui, dari 52 siswa atau $100 \%$ belum mencapai ketuntasan belajar. Dari hasil pengamatan dan tes awal yang dilakukan peneliti terhadap siswa kelas $\mathrm{V}$, dapat diperoleh keterangan bahwa hasil belajar siswa rendah, maka perlu adanya perbaikan dalam proses pembelajaran Ilmu Pengetahuan Sosial. Dan untuk memperbaikinya maka perlu dilakukan penelitian eksperimen dengan menggunakan model pembelajaran Problem Based Learning. Setelah dilakukan proses pembelajaran pada kelas eksperimen dan kelas kontrol dengan menggunakan metode yang berbeda, maka dilakukan post-test (tes akhir) untuk mengetahui ada tidaknya peningkatan kemampuan hasil belajar siswa tersebut. Berikut ini disajikan dalam bentuk tabel deskripsi post-test kelas eksperimen dan kelas kontrol.

\section{Deskripsi Kemampuan Akhir Siswa kelas Kontrol dan Kelas Eksperimen}

\begin{tabular}{|c|l|c|c|}
\hline \multirow{2}{*}{ NO } & \multirow{2}{*}{ Data Penelitian } & \multicolumn{2}{|c|}{ Kelompok } \\
\cline { 3 - 4 } & & Kontrol & Eksperimen \\
\hline 1 & Jumlah siswa & 25 & 27 \\
\hline 2 & Skor max & 93 & 93 \\
\hline 3 & Skor min & 40 & 60 \\
\hline 4 & Rata-rata skor & 59,4 & 79,85 \\
\hline 5 & Standar deviasi & 13,48 & 8,82 \\
\hline
\end{tabular}

Berdasarkan tabel di atas, dapat dilihat bahwa perolehan nilai hasil belajar siswa pada kelas eksperimen mengalami peningkatan yang sangat signifikan yaitu dengan ketuntasan presentase sebesar 79,85\% yang mendapatkan nilai sesuai dengan KKM 70, sedangkan pada kelas kontrol presentase sebesar 59,4\% yang 
medapatkan nilai dengan KKM 70. Peningkatan ini dikarenakan guru sudah dapat menguasai kelas, sehingga materi yang akan disampaikan, dapat diterima siswa dengan baik. Dan akhirnya hasil belajar siswa meningkat. Untuk mengetahui peningkatan hasil belajar siswa dengan menggunakan model pembelajaran Problem Based Learning pada kelas eksperimen dan metode ceramah pada kelas kontrol digunakan perhitungan uji gain. Berikut ini disajikan tabel deskripsi gain kelas eksperimen dan kelas kontrol.

\section{Deskripsi Peningkatan Siswa kelas Kontrol dan Kelas Eksperimen}

\begin{tabular}{|l|c|c|c|c|}
\hline \multicolumn{1}{|c|}{ Kelas } & $\begin{array}{c}\text { Rata-rata } \\
\text { Posttest }\end{array}$ & $\begin{array}{c}\text { Rata-rata } \\
\text { Pretest }\end{array}$ & Gain & Ket \\
\hline Kontrol & 59,4 & 49,6 & 0,15 & Rendah \\
\hline Eksperimen & 79,85 & 53,11 & 0,55 & Sedang \\
\hline
\end{tabular}

Berdasarkan data nilai pre-test dan post-test pada kelas eksperimen diperoleh nilai gain sebesar 0,55 dan pada kelas kontrol sebesar 0,15. Nilai tersebut selanjutanya diinterpretasikan ke dalam kriteria $N$-gain. Setelah diinterpretasikan diperoleh nilai $\mathrm{N}$-gain kelas kontrol tergolong rendah, sedangkan untuk kelas eksperimen dengan penggunaan model pembelajaran Problem Based Learning memiliki nilai $\mathrm{N}$-gain yang tergolong sedang. Selanjutnya dilakukan Uji perbedaan dua rata-rata pada post-test tujuanya yaitu untuk mengetahui kemampuan siswa kelas kontrol dan kelas eksperimen setelah dilakukan pembelajaran. Berikut ini disajikan tabel kelas eksperimen dan kelas control.

Uji t Post-Test Kelas Eksperimen dan Kelas Kontrol

\begin{tabular}{|l|c|c|c|c|c|}
\hline \multicolumn{1}{|c|}{ Kelas } & Rata-rata & Variansi & $\begin{array}{c}\text { Jumlah } \\
\text { siswa }\end{array}$ & t-hit & t-tabel \\
\hline Kontrol & 59,4 & 77,80 & 25 & 6,50 & 2,69 \\
\hline Eksperimen & 79,85 & 181,71 & 27 & & \\
\hline
\end{tabular}

Berdasarkan hasil uji-t diperoleh $t_{\text {hitung }}=6,50$ dengan mengambil taraf signifikansi $95 \%$ diperoleh $\mathrm{t}_{\text {tabel }}=\mathrm{t}_{0,95(50)}$ dengan demikian $\mathrm{t}_{\text {hitung }}(6,50)>\mathrm{t}_{\text {tabel }}(2,96)$, maka $\mathrm{H}_{0}$ ditolak dan $\mathrm{H}_{\mathrm{a}}$ diterima artinya terdapat perbedaan hasil Posttest antara kelas eksperimen dan kelas kontrol. Dengan demikian model pembelajaran Problem Based Learning meningkatkan pemahaman konsep siswa lebih tinggi dibandingkan dengan metode ceramah. 
Berdasarkan hasil analisis terhadap skor rata-rata pre-test pada kelas yang menggunakan metode ceramah diperoleh rata-rata skor pre-test yaitu 49,6 sedangkan pada kelas yang menggunakan model pembelajaran Problem Based Learning 53,11. Artinya tidak terdapat perbedaan yang signifikan antara nilai ratarata pre-test kelas kontrol dan kelas eksperimen. Setelah dilakukan pembelajaran pada kedua kelas dengan penggunaan model pembelajaran Problem Based Learning pada kelas eksperimen dan Metode Ceramah pada kelas kontrol selanjutnya diberikan post-test untuk mengetahui hasil belajar siswa. Kemudian dilakukan analisis terhadap hasil post-test kedua kelas tersebut. Hasil analisis menunjukan bahwa kedua kelas tersebut mengalami peningkatan dalam hasil belajar, namun peningkatan pada kelas eksperimen memiliki kemampuan yang lebih baik daripada kelas kontrol dalam hasil belajar. Hal ini terlihat dari perolehan rata-rata nilai post-test kelas eksperimen yaitu 79,85 dan nilai rata-rata kelas kontrol yaitu 59,4. Artinya, terdapat perbedaan nilai rata-rata kelas antara kelas eksperimen dan kelas kontrol. Selain itu, berdasarkan hasil pengujian dengan menggunakan uji kesamaan dua rata-rata (uji t) dari hasil post-test diperoleh $t_{\text {hitung }} 6,50>\mathrm{t}_{\text {tabel }} 2,96$. Ini berarti terdapat perbedaan yang signifikan antara hasil post-test kelas eksperimen dan kelas kontrol.

Berdasarkan hasil analisis di atas siswa yang menggunakan model pembelajaran Problem Based Learning hasil belajarnya lebih meningkat bila dibandingkan dengan siswa yang memperoleh metode ceramah. Meningkatnya pencapaian hasil belajar siswa yang menggunakan model pembelajaran Problem Based Learning dimungkinkan karena dalam pembelajaran tersebut, siswa ikut terlibat aktif dalam proses pembelajaran dan memecahkan masalah yang berkaitam dengan kehidupan, serta bertanggung jawab atas pembelajarannya. Penggunaan model pembelajaran Problem Based Learning memfasilitasi pembelajaran siswa dengan menekankan masalah dan penyelesaian masalah sehingga siswa mampu meningkatkan kemampuan pembelajaran yang lebih bermakna, berpikir tingkat tinggi dan mampu menyelesaikan masalah dengan benar yang berarti siswa memiliki kemampuan pemahaman terhadap suatu konsep. 


\section{DAFTAR PUSTAKA}

Abdul Haris, Muhammad. (2013). Pengaruh Penerapan Model Problem Based Learning Terhadap Kemampuan Memecahkan Masalah Dalam Pembelajaran Ilmu Pengetahuan Sosial Pada Siswa Kelas IV SD N Blondo 1 Magelang. Sarjana Pendidikan pada FIP UNY Yogyakarta: tidak diterbitkan.

Al Muchtar. (2007). Ilmu dan Aplikasi Pendidikan. Bandung: PT Imperial Bhakti Utama.

Arends, Richard I. (1997). Classroom Instruction and Management. New York: Mac Millan Publishing.

Arikunto, Suharsimi. (2006). Manajemen Penelitian. Jakarta: Rineka Cipta.

Cahyo, Edo Dwi Cahyo. (2015). "Pengaruh Penerapan Model Problem Based Learning Dalam Meningkatkan PemahamanKonsep Dasar IPS dan Kemampuan Berpikir Kritis Siswa". Tersedia di http://onesearch.id/Record/IOS2897.17591_[diunduh tanggal 04 Juni 2017]

Cheiriyah, Idha. (2008). Meningkatkan pemahaman konsep mata pelajaran Biologi melalui performance assesment. Dalam Jurnal Pendidikan Inovassi. Volume 3 (2).

Daryanto. (2008). Dasar-dasar Proses Pembelajaran. Yogyakarta: Kanisius.

Detsy. (2004). Teknik penilaian Prestasi Belajar Siswa. Bandung: Pustaka Setia.

Dewi Kurnia, Yulia. (2015). "Pengaruh Penerapan Model Problem Based Learning terhadap PemahamanKonsep Mitigasi Bencana Pada Mata Pelajaran IPS Siswa Kelas V (Penelitian Kuasi Eksperimen di SD Islam AlHasanah Ciledug, Tangerang. Tersedia dihttps://idtesis.com/model-problembased-learning-dalam-pembelajaran-sejarah/[diunduh tanggal 04 Juni 2017]

Hamalik, Oemar. (2003). Perencanaan pengajaran berdasarkan pendekatan sistem. Jakarta: Bumi Aksara.

Kusumawati, Nila. (2008). Pemahaman konsep matematika dalam pembelajaran matematika. Jurnal Pendidikan. Pdf. Free.

Mergendoller,J.R, dkk. (2000). The Effectiveness Of Problem Based Instruction. Journal Of Education Research. Tersedia di: http://projects.coe.uga.edu/epltt/index .php? title=Proble Based Instruction[diunduh tanggal 04Juni 2017].

Endi, Nurgana. (1993). Statistik Penelitian. Bandung: CV Permadi.

Oktafoura Suminar, Serra. dan Intansari Meilani, Rini. (2016). Pengaruh Model Pembelajaran Discovery Learning dan Problem Based Learning Terhadap Prestasi.

Prianto, Agus. (2016). Diktat Statistik. Universitas Kuningan. 
Purwanto, M.N. (1994). Prinsip-prinsip dan Teknik Evaluasi Pengajaran Pendidikan. Bandung: Remaja Rosdakarya

Ruseffendi, E.T. (1998). Statistika dasar untuk penelitian pendidikan.Bandung: IKIP Bandung Press.

Rusmono. (2014). Strategi Pembelajaran dengan Problem Based Learning itu perlu. Bogor: Ghalia Indonesia.

Sapriya. (2006). Pendidikan IPS: Konsep dan Pembelajaran. Bandung: PT Remaja Rosda Karya

Sugiyono. (2011). Metode Penelitian Kuantitatif, Kualitatif dan R\&D. Bandung: Alfabeta.

Sugiyono. (2014). Statistik untuk Penelitian. Bandung: CV ALFABETA

Suharsaputra, Uhar. (2012). Metode Penelitian Kuantitatif, Kualitatif dan Tindakan. Bandung: PT Refika Aditama

Suharsaputra, Uhar. (2011). Administrasi Pendidikan. Bandung: Refika Aditama Supriatna, Nana, Srie, Mulyani, \& Ade, Rokhayati, Ade. (2007). Pendidikan IPS di $S D$. Bandung: UPI PRESS.

Susanto, Ahmad. (2014). Pengembangan Pembelajaran IPS. Jakarta. Prenadamedia Group.

Trianto. (2009).Mendesain Model Pembelajaran InvatifProgresif. Jakarta: Kencana Prenada Group.

Undang-Undang Republik Indonesia Nomor 20. (2003). Sistem Pendidikan Nasional. Tersedia pada. www.unpad.ac.id/wp.../UU20-2003-Sisdiknas.pdf diakses pada tanggal 01 Februari 2017.

Vetsari. (2009). Pemahaman dan Hasil Belajar Siswa. Surabaya: Kartika. 